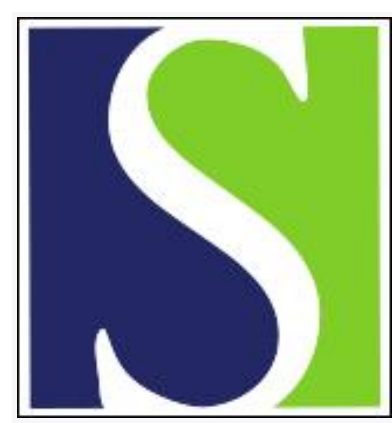

Scand J Work Environ Health 1998;24(3):175-182

https://doi.org/10.5271/sjweh.296

Issue date: Jun 1998

Epidemiology of occupational and environmental risk factors related to ovarian cancer

by Shen N, Weiderpass E, Anttila A, Goldberg MS, Vasama-Neuvonen KM, Boffetta P, Vainio HU, Partanen TJ

The following articles refer to this text: 2001;27(3):161-213;

2004;30(5):356-361; 2007;33(1):66-73

Key terms: etiology; exposure; occupation; ovarian neoplasms; review

This article in PubMed: www.ncbi.nlm.nih.gov/pubmed/9710369 


\title{
Epidemiology of occupational and environmental risk factors related to ovarian cancer
}

\author{
by Ningyan Shen, MD, MSc, ${ }^{1,3}$ Elisabete Weiderpass, MD, ${ }^{2,3}$ Ahti Anttila, PhD, ${ }^{3,4}$ Mark S Goldberg, \\ PhD,,${ }^{1,7}$ Kaisa M Vasama-Neuvonen, MSc, ${ }^{3}$ Paolo Boffetta, MD, ${ }^{5}$ Harri U Vainio, MD, ${ }^{6}$ \\ Timo J Partanen, PhD
}

Shen N, Weiderpass E, Anttila A, Goldberg MS, Vasama-Neuvonen KM, Boffetta P, Vainio HU, Partanen TJ. Epidemiology of occupational and environmental risk factors related to ovarian cancer. Scand $J$ Work Environ Health 1998;24(3):175-82.

\begin{abstract}
This paper reviews articles published during 1970-1997 from 48 epidemiologic studies on occupational and environmental risk factors of ovarian cancer. Current evidence is characterized by poorly focused data for occupational and environmental agents, vulnerability to biases, and an almost complete lack of quantitative exposure-response data. The moderate amount of data on nurses, teachers, professionals, dry cleaning employees, women in agriculture, the pharmaceutical industry, pharmacists, waitresses, and cooks show very little, if any, evidence of excess risk. Hairdressers, beauticians, and women employed in the printing industry may be at increased risk, but the data are insufficient for strong conclusions. Some case-referent studies suggest a modest-to-moderate excess in association with genital talc application. Few high-quality studies have been carried out, and no chemical agents have been studied extensively, with the exception of exposure to talc. Ovarian cancer may have occupational and environmental etiologies intertwined with cultural, behavioral, and life-style factors and genetic susceptibility, but current knowledge is insufficient to quantify occupational and environmental etiologies reliably. Well-designed analytic epidemiologic studies with sufficient power are needed.
\end{abstract}

Key terms etiology, exposure, occupation, ovarian neoplasms, review.

\section{Descriptive epidemiology}

Ovarian cancer (ICD-9 183) is the primary cause of gynecological cancer fatalities in several industrialized countries, and it ranks in the top 10 of cancers in women (1). An estimated 162000 new cases were diagnosed worldwide in 1985 (2). A considerable proportion of cases is diagnosed at advanced stages (3), when response to treatment is poor. The incidence of ovarian cancer increases rapidly until 80 years of age (4). The role of occupational and environmental agents in the development of ovarian cancer is poorly understood. Improved knowledge of these factors would probably lead to a decrease in the burden of ovarian cancer among the elderly if exposures were reduced at earlier ages.
Some characteristics of the general epidemiology of ovarian cancer indirectly suggest cultural, life-style, and environmental factors as influencing its etiology. First, ovarian cancer incidence and mortality show a 7-fold variation between populations, the highest figures being reported for northern and western Europe and North America (5), where rates have been increasing and subsequently stabilized or decreased. Extensive use of oral contraceptives, supposedly protective against ovarian cancer, may explain the decreases (6). For a number of low-rate populations, on the other hand, increasing trends in incidence and mortality have been observed (7). Second, the risk of ovarian cancer among migrants becomes similar to that of the host country $(8,9)$. As for social gradients within national populations, however, the data are not

1 Department of Epidemiology and Biostatistics, McGill University, Montreal, Canada.

2 Department of Medical Epidemiology, Karolinska Institute, Stockholm, Sweden.

3 Department of Epidemiology and Biostatistics, Finnish Institute of Occupational Health, Helsinki, Finland.

$4 \quad$ Finnish Cancer Registry, Helsinki, Finland.

5 Unit of Environmental Cancer Epidemiology, International Agency for Research on Cancer, Lyon, France.

6 Unit of Cancer Chemoprevention, International Agency for Research on Cancer, Lyon, France.

7 Epidemiology and Biostatistics Unit, Institute Armand-Frappier, University of Quebec, Laval, Quebec, Canada.

Reprint requests to: Dr Timo Partanen, Finnish Institute of Occupational Health, Topeliuksenkatu 41 a A, FIN-00250 Helsinki, Finland. [e-mail: Timo.Partanen@occuphealth.fi] 
helpful for clues because of inconsistencies. For example, in Brazil, Italy, and Colombia, higher social strata exhibit excess mortality or incidence of ovarian cancer, while northern European data suggest no consistent trends in social class (10).

Epidemiologic reviews on the etiology of ovarian cancer are available $(1,3,11-16)$. Parity and maternal age at first birth (17-27), use of combined oral contraceptives $(8,24,28-34)$, and early age at menopause $(17$, $20,35)$ seem to be protective. Data on hormonal replacement therapy are inconsistent (12). Dietary factors are probably involved, and fat, protein, and calorie intake are potential risk factors (36). Smoking, alcohol, coffee, and tea are probably not risk factors for ovarian cancer (37-42).

There is a strong familial component to ovarian cancer $(43,44)$. Ovarian cancers in some breast cancer families are due to a breast cancer susceptibility locus on chromosome 17 (45). The breast cancer susceptibility gene, BRCA1, may act as an inhibitor of cell proliferation. Locations of other genes for ovarian cancer susceptibility have been suggested (46-48). Thus the ovarian cancer risk due to a second major breast cancer susceptibility gene (BRCA2) on chromosome 13q is elevated over that of the general population, although less so than for BRCA1. BRCA1 and BRCA2 together would explain about $6 \%$ of the ovarian cancers of northern European populations (Goldgar D, personal communication). Loss of heterozygosity on chromosome $13 \mathrm{q}$ occurs in $50-60 \%$ of sporadic ovarian cancers (49). However, no clearly diseasecausing somatic mutations have been observed for sporadic ovarian cancers.

The epidemiologic literature contains data on the risk of ovarian cancer for some 40 job titles. This review summarizes epidemiologic results published during the past 28 years on occupational and environmental risk factors.

\section{Material and methods}

Reports and articles published in 1970-1997 that provided data on the occupational and environmental etiology of ovarian cancer were identified by MEDLINE searches, from reference lists of papers on ovarian cancer published in major scientific journals, from the perusal of journals, and from an inspection of publications of the International Agency for Research on Cancer. When the ecological studies are excluded, a total of 48 studies were reviewed. There were 12 population- or hospital-based case-referent studies, 15 occupational cohort studies, 11 record-linkage studies, and 10 proportionate mortality studies. A total of 20 studies reported mortality data, while 28 studies were based on incident cases.

There were recurrent quality problems in the studies. None of the proportionate mortality, record-linkage, or occupational cohort studies controlled for potential confounding by reproductive determinants of ovarian cancer. Another feature was the almost exclusive use of job titles and industries that could lead to misclassification because of heterogeneity in exposure to chemical and physical agents. Even the validity of classifying subjects into job and industry categories, particularly in recordlinkage and proportionate mortality studies, can often be questioned, since the data usually derive from cross-sectional censuses or from death records. The probability of misclassification of job or industry is increased since the data sources usually provide poor surrogates for lifelong or usual job or industry.

\section{Occupational hazards for ovarian cancer}

Nurses. Data on ovarian cancer risk for nurses were available in 1 occupational cohort study with a small number of cases (50), 2 record-linkage studies $(51,52)$, and 4 proportionate mortality studies $(18,53-55)$ (table 1$)$. The cohort study found a nonsignificant excess for Icelandic nurses with over 20 years of employment. The Finnish linkage study $(51,52)$ found no excess for nurses, even after adjustment for social status. The Italian linkage and proportionate studies (52) had too few cases. No excess was found in the proportionate mortality studies from the United Kingdom (UK) (54) or the United States (US) (55). The UK study (54) reported an excess for physiotherapists. A proportionate mortality study in British Columbia $(18,53)$ reported significantly elevated risks for breast or ovarian cancer among teachers, nurses, office clerks, and sales clerks. When homemakers were excluded from the reference population, however, most of the excesses for breast and ovarian cancers in the 4 occupational groups disappeared. The results therefore indicate confounding by reproductive factors.

Teachers. Only proportionate mortality studies were available for teachers. No unusual pattern of risk was found for teachers in 3 European $(51,52)$ studies and 1 Canadian (53) study. The latter reported a $70 \%$ excess, but the estimate was unstable. In the UK study (54), a significant $50 \%$ excess was reported.

Professionals. Professional occupations is a large category and is likely to be a heterogeneous entity in terms of work, exposures, and life-style. A Chinese case-referent study (17) reported a $40 \%$ nonsignificant excess for professionals and scientists. Another Chinese study (56) found an increased risk of ovarian cancer for professionals and scientists [standardized incidence ratio (SIR) 1.3, $\mathrm{P}<0.05]$, but occupational information for the cases and the comparison population came from different sources and therefore the result may have been biased in an unknown direction. Proportionate mortality data from the United Kingdom $(54,57)$ suggested elevated risks for 
Table 1. Summary of studies of occupation and ovarian cancer. $(C-R=$ case-referent study, $95 \% \mathrm{Cl}=95 \%$ confidence interval, $\mathrm{COH}=$ occupational cohort study, $I R=$ incidence ratio, $M O R=$ mortality odds ratio, $N E C=$ not elsewhere classified, $N S=$ not significant $(P>0.05)$, $\mathrm{OPCS}=$ Office of Population Censuses and Surveys, $\mathrm{OR}=$ odds ratio, $\mathrm{PCMR}=$ proportionate cancer mortality ratio, $\mathrm{PMR}=$ proportionate mortality ratio and proportionate mortality study, $P R R=$ proportionate registration ratio, $R-L=$ record-linkage study, $S I R=$ standardized incidence ratio, SMR = standardized mortality ratio)

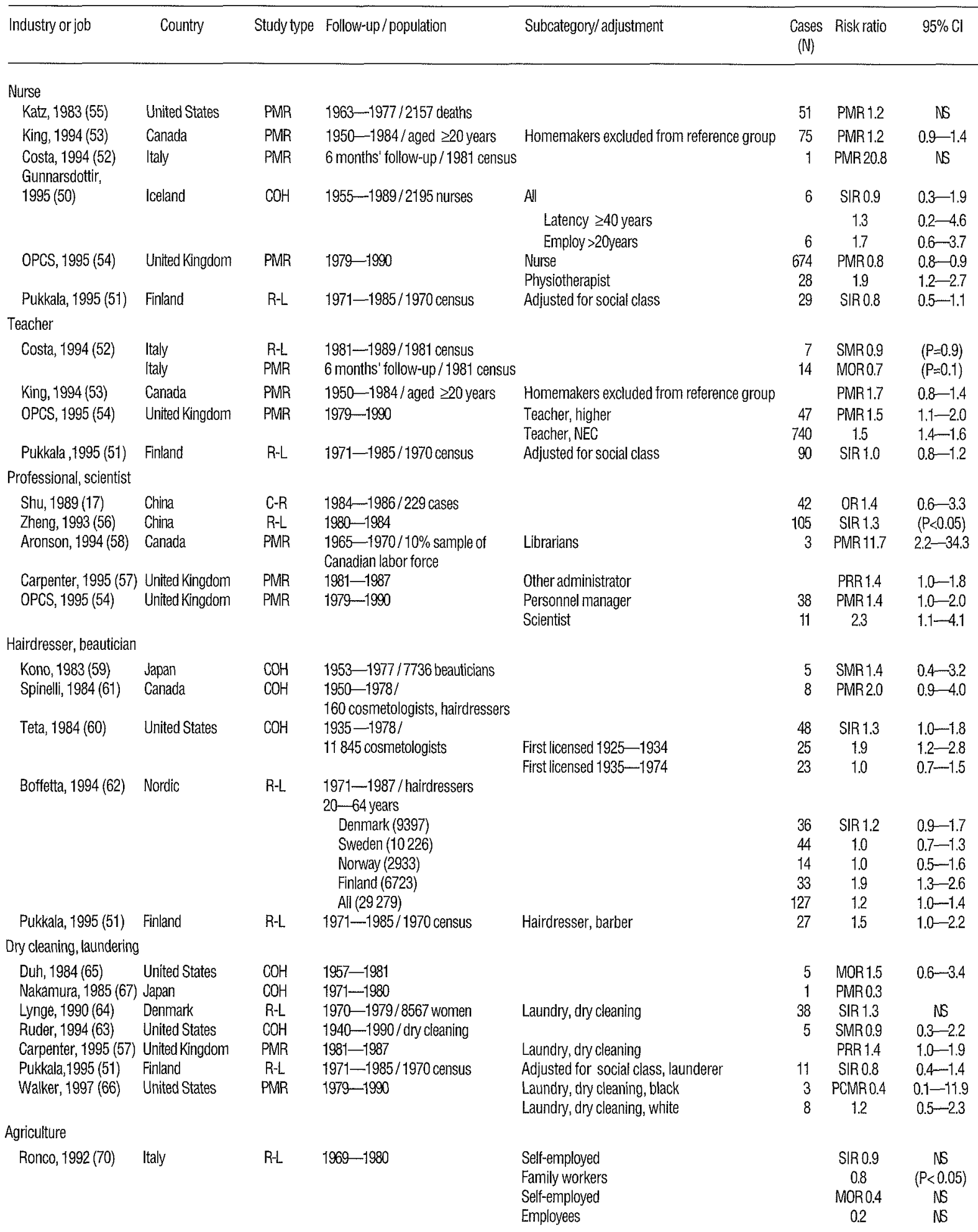


Table 1. Continued.

\begin{tabular}{|c|c|c|c|c|c|c|c|}
\hline Industry/job & Country & Study type & Follow-up/population & Subcategory/adjustment & $\begin{array}{l}\text { Cases } \\
\text { (N) }\end{array}$ & Risk ratio & $95 \% \mathrm{Cl}$ \\
\hline Aronson, 1994 (58) & Canada & R-L & $1965-71$ & Agricultural implements & 2 & SMR 11.2 & $1.4-40.5$ \\
\hline Wiklund, 1994 (71) & Sweden & $R-L$ & $1971-1987 / 1970$ census & Agricultural worker & 323 & SIR 0.9 & $0.8-1.0$ \\
\hline \multirow[t]{6}{*}{ Pukkala, 1995 (51) } & Finland & ADM & $1971-1985 / 1970$ census & Adjusted for social class & & & \\
\hline & & & & Farmer & 111 & $\operatorname{SIR} 1.3$ & $0.9-1.2$ \\
\hline & & & & Agricultural worker & 35 & 1.0 & $0.7-1.4$ \\
\hline & & & & Gardener & 15 & 1.3 & $0.7-2.1$ \\
\hline & & & & Livestock worker & 222 & 0.8 & $0.7-0.9$ \\
\hline & & & & Agricultural worker, unspecifed & 3 & 10.3 & $2.1-30$ \\
\hline Folsom, $1996(72)$ & United States & $\mathrm{COH}$ & $1986-1992$ & Farm versus nonfarm & 16 & IR 0.8 & $0.5-1.4$ \\
\hline Inskip, 1996 (68) & United Kingdom & PMR & $1979-1990$ & $\begin{array}{l}\text { Farmer } \\
\text { Farmers' wife }\end{array}$ & $\begin{array}{r}94 \\
930\end{array}$ & $\begin{array}{l}\text { PCMR1.2 } \\
1.0\end{array}$ & $\begin{array}{l}1.0-1.5 \\
1.0-1.1\end{array}$ \\
\hline Kristensen, 1996 (69) & Norway & $\mathrm{COH}$ & $1969-1991$ & $\begin{array}{l}\text { Agriculture } \\
\text { Chicken farming }\end{array}$ & $\begin{array}{r}147 \\
47\end{array}$ & $\begin{array}{l}\text { SIR } 0.9 \\
1.5\end{array}$ & $\begin{array}{l}0.8-1.1 \\
1.1-2.2\end{array}$ \\
\hline Waterhouse, 1996 (73) & United States & $\mathrm{COH}$ & 1959-1987/3484 women & Rural area & 17 & SIR 0.9 & $0.5-1.4$ \\
\hline \multicolumn{8}{|l|}{ Rubber manufacture } \\
\hline Pukkala, (51) & Finland & R-L & $1971-1985 / 1970$ census & & 9 & $\operatorname{SIR} 2.4$ & $1.1-4.6$ \\
\hline \multicolumn{8}{|l|}{ Telephone industry } \\
\hline Dosemeci, 1994 (74) & United States & PMR & $\begin{array}{l}\text { 1984-1989/148 ovarian } \\
\text { cancer deaths }\end{array}$ & $\begin{array}{l}\text { White } \\
\text { Black } \\
\text { White and black } \\
\text { Office } \\
\text { Operator } \\
\text { Engineer, technician } \\
\text { Mechanic, repairer }\end{array}$ & $\begin{array}{r}148 \\
5 \\
27 \\
6 \\
3 \\
3 \\
1\end{array}$ & $\begin{array}{l}\text { MOR } 1.4 \\
2.1 \\
1.4 \\
2.1 \\
1.3 \\
6.6 \\
1.1\end{array}$ & $\begin{array}{r}1.1-1.6 \\
0.9-4.8 \\
1.0-2.0 \\
0.9-4.6 \\
0.4-3.9 \\
3.0-14.4 \\
0.2-7.2\end{array}$ \\
\hline \multicolumn{8}{|c|}{ Pharmaceutical industry, pharmacists, chemists } \\
\hline $\begin{array}{l}\text { Walrath, } 1985(78) \\
\text { Shu, 1989 (17) } \\
\text { Hansen, 1994 (75) } \\
\text { Hansen, 1994 (76) } \\
\text { Edling, 1995 (77) } \\
\text { Pukkala, 1995 (51) } \\
\text { Waitress, cook }\end{array}$ & $\begin{array}{l}\text { United States } \\
\text { China } \\
\text { Denmark } \\
\text { Denmark } \\
\text { Sweden } \\
\text { Finland }\end{array}$ & $\begin{array}{l}\text { PMR } \\
C-R \\
C O H \\
C O H \\
R-L \\
R-L\end{array}$ & $\begin{array}{l}1925-1979 \\
1964-1989 / 5554 \text { women } \\
1970-1990 \\
1960-1990 / 1693 \\
1971-1985 / 1970 \text { census }\end{array}$ & $\begin{array}{l}\text { Chemist } \\
\text { Pharmaceutical employee } \\
\text { Pharmaceutical plant } \\
\text { Pharmacy technicians } \\
\text { Pharmeceutical employee and chemist } \\
\text { Adjusted for social class, pharmacists }\end{array}$ & $\begin{array}{r}13 \\
11 \\
14 \\
2 \\
7\end{array}$ & $\begin{array}{l}\text { PMR } 2.2 \\
\text { OR } 2.7 \\
\text { SIR } 0.8 \\
\text { SIR } 1.2 \\
\text { SIR } 1.0 \\
\text { OR } 0.6\end{array}$ & $\begin{array}{r}1.1-4.2 \\
0.6-13.9 \\
0.4-1.4 \\
0.6-1.9 \\
0.1-3.6 \\
0.3-1.3\end{array}$ \\
\hline \multirow{2}{*}{$\begin{array}{l}\text { Shu, } 1989(17) \\
\text { Burnet, } 1994(80)\end{array}$} & China & $C-R$ & $1980-1984$ & Waitress & & OR 1.3 & $0.6-3.0$ \\
\hline & United States & R-L & 1971 -1990/waitresses & $\begin{array}{l}\text { White } \\
\text { Black }\end{array}$ & $\begin{array}{r}168 \\
4\end{array}$ & $\begin{array}{l}\text { PMR } 0.7 \\
\text { PMR } 0.7\end{array}$ & $\begin{array}{l}0.6-0.8 \\
0.2-1.7\end{array}$ \\
\hline Costa, 1994 (52) & Italy & PMR & 1981-1989/1981 census & & 4 & MOR 1.1 & $(P=0.83)$ \\
\hline Pukkala, 1995 (51) & Finland & $R-L$ & $1971-1985 / 1970$ census & $\begin{array}{l}\text { Adjusted for social class } \\
\text { Chets, cooks } \\
\text { Kitchen assistant } \\
\text { Waitress }\end{array}$ & $\begin{array}{l}42 \\
42 \\
50\end{array}$ & $\begin{array}{l}\text { SIR } 1.4 \\
\text { SIR } 1.1 \\
\text { SIR } 1.1\end{array}$ & $\begin{array}{l}1.0-1.8 \\
0.8-1.5 \\
0.8-1.4\end{array}$ \\
\hline OPCS, $1995(54)$ & United Kingdom & PMR & $1979-1990$ & $\begin{array}{l}\text { Publicans, bar staff } \\
\text { Cook }\end{array}$ & $\begin{array}{l}149 \\
303\end{array}$ & $\begin{array}{l}\text { PMR0.7 } \\
0.8\end{array}$ & $\begin{array}{l}0.6-0.9 \\
0.7-0.9\end{array}$ \\
\hline \multicolumn{8}{|l|}{ Printing industry } \\
\hline Malker, 1987 (81) & Sweden & ADM & $1961-1973 / 1960$ census & Graphics industry & 29 & $\operatorname{SIR} 1.4$ & NS \\
\hline $\begin{array}{l}\text { Costa, } 1994 \text { (52) } \\
\text { Carpenter, 1995 (57) }\end{array}$ & $\begin{array}{l}\text { Italy } \\
\text { United Kingdom }\end{array}$ & $\begin{array}{l}\text { R-L } \\
\text { PMR }\end{array}$ & $\begin{array}{l}1981-1989 / 1980 \text { census } \\
1981-1987\end{array}$ & Printing and publishing & 3 & $\begin{array}{l}\text { SMR3.2 } \\
\text { PRR2.3 }\end{array}$ & $\begin{array}{l}0.3-5.0 \\
1.1-4.3\end{array}$ \\
\hline Lynge, 1995 (82) & Denmark & R-L & $1970-1987 / 1970$ census & $\begin{array}{l}\text { Typographer / lithographer / photoengraver } \\
\text { Bookbinder } \\
\text { Bookbinders' assistant }\end{array}$ & $\begin{array}{l}1 \\
1 \\
6\end{array}$ & $\begin{array}{l}\text { SIR2.1 } \\
1.9 \\
08\end{array}$ & $\begin{array}{l}0.1-11.6 \\
0.0-10.7 \\
0.3-1.8\end{array}$ \\
\hline Pukkala, 1995 (51) & Finland & R-L & $1971-1985 / 1970$ census & $\begin{array}{l}\text { Printing industry } \\
\text { Typographer } \\
\text { Lithographer } \\
\text { Bookbinder } \\
\text { Unspecific }\end{array}$ & $\begin{array}{r}30 \\
8 \\
3 \\
10 \\
5\end{array}$ & $\begin{array}{c}\text { SIR } 2.2 \\
3.3 \\
5.4 \\
1.5 \\
3.3\end{array}$ & $\begin{array}{l}1.5-3.1 \\
1.4-6.5 \\
1.1-1.6 \\
0.7-2.7 \\
1.1-7.6\end{array}$ \\
\hline \multicolumn{8}{|c|}{ Miscellaneous industrial workers } \\
\hline $\begin{array}{l}\text { Gunnarsdottir, } \\
\text { 1992 (79) }\end{array}$ & Iceland & $\mathrm{COH}$ & $1970-1986 / 18878$ & Manual worker, hired over 10 years & & SMR1.4 & $0.6-2.9$ \\
\hline Costa, 1994 (52) & Italy & PMR & $1981-1989 / 1981$ census & $\begin{array}{l}\text { Metalworker } \\
\text { Clothing worker }\end{array}$ & $\begin{array}{l}5 \\
7\end{array}$ & $\begin{array}{l}\text { MOR } 5.2 \\
\text { MOR } 2.9\end{array}$ & $\begin{array}{l}(P<0.01) \\
(P<0.01)\end{array}$ \\
\hline OPCS, $1995(54)$ & United Kingdom & PMR & $1979-1990$ & $\begin{array}{l}\text { Sewer, embroiderer } \\
\text { Spinner, winder } \\
\text { Machine tool operator } \\
\text { Packer, sorter }\end{array}$ & $\begin{array}{r}294 \\
43 \\
95 \\
198\end{array}$ & $\begin{array}{l}\text { PMR } 0.9 \\
0.6 \\
0.8 \\
0.8\end{array}$ & $\begin{array}{l}0.8-1.0 \\
0.4-0.8 \\
0.7-1.0 \\
0.7-1.0\end{array}$ \\
\hline
\end{tabular}


personnel managers, other administrators, and scientists. A Canadian proportionate mortality study (58) reported a large excess for librarians, but the finding was based on only 3 cases.

Hairdressers and beauticians. Two occupational cohort studies of beauticians, one from Japan (59) and the other (the largest) from the United States $(60)$, reported a $30-40 \%$ excess of ovarian cancer risk for beauticians. In addition, 3 record-linkage and proportionate mortality studies $(51,61,62)$ were available. A Canadian proportionate mortality study reported a doubling of the risk for hairdressers and cosmetologists (61). A record-linkage study (62) reported a slight excess for hairdressers in 4 Nordic countries. The country-specific SIR values ranged from 1.0 (Norway and Sweden) to 1.9 (Finland). Finally, Pukkala (51) reported an excess in Finland, the population overlapping with the one in the study of Boffetta et al (62).

Dry cleaning. Both nonchlorinated and chlorinated solvents have been used in dry cleaning, and the type of solvent used has varied considerably over time and location. Epidemiologic data come from 1 US occupational cohort study (63), 2 Nordic record-linkage studies $(51,64), 2$ overlapping British studies $(54,57), 2$ US proportionate mortality studies $(65,66)$, and a Japanese proportionate mortality study (67) with very small numbers. Except for a $40 \%$ excess in 1 of the British studies (57) and a $30 \%$ excess of borderline significance in the Danish recordlinkage study (64) for employees in laundries and dry cleaning, no indications of excess risk were observed.

Agriculture, farming. Hazardous exposures in agriculture and farming include agrochemicals, fuels, solvents, paints, dusts, fumes, viruses, fungi, and solar radiation. No indications of excess risks were found in large categories of agriculture or farming in Europe (54, 68-73). Excesses were found for 3 subcategories: unspecified agricultural workers in Finland (51) ( 3 cases), the industrial category "agricultural implements" in Canada (58) ( 2 cases), and chicken farming in Norway (69) (47 cases).

Rubber manufacturing. The only source of data for rubber manufacturing was the Finnish census-cancer incidence linkage study (51). The risk of ovarian cancer for employees in the rubber industry, adjusted for social class, was elevated.

Telephone industry. The results of 1 proportionate mortality study in the telephone industry (74), conducted in 24 US states, were available. Excesses were found for both white and black women, and for engineers, technicians, office workers, telephone operators, mechanics, and repairers.
Pharmaceutical industry, pharmacists, chemists. Three occupational cohort studies were available for the pharmaceutical industry, pharmacists and chemists, all from Nordic countries. A $40 \%$ excess in ovarian cancer risk was reported for employees in a Danish pharmaceutical company (75), while no excess was found for Danish pharmaceutical technicians (76) or for employees in a Swedish pharmaceutical company (77). The Finnish record-linkage study (51) found no excess for pharmacists. On the other hand, a community-based case-referent study in China (21) found an excess for women in the pharmaceutical industry, and a US proportionate mortality study (78) found an excess for chemists.

Miscellaneous industrial workers. No clear excess ovarian cancer risk was found in an occupational cohort study of manual workers in different industries in Iceland in 1970-1986 (79). In an Italian proportionate mortality study (52), significantly increased risks were found for metal workers and clothing workers. The UK proportionate mortality study (53) found low risks for sewers and embroiderers, spinners and winders, machine tool operators, and packers and sorters.

Waitresses, cooks. One case-referent study (18) and 5 record-linkage and proportionate mortality studies $(51,52$, $54,80)$ were available. A small-sized population-based case-referent study (18) in Shanghai, China, reported a nonsignificant $30 \%$ excess for waitresses. The Italian proportionate mortality (52) and record-linkage (52) studies found no excess. In the Finnish record-linkage study (51), the waitresses' SIR values were close to unity, and deficits were found in large US (80) and UK (54) proportionate mortality studies.

Printing industry. Positive associations between ovarian cancer and work in the printing industry have been reported in 1 large record-linkage study from Finland (51) and a UK proportionate mortality study (57). In the linkage study (51), significantly positive associations were found for the printing industry and for a number of specific occupational categories within the printing industry. Similar results have been obtained in Italy (52), but, as there were only 3 cases, the estimate was highly unstable. No associations were found for women working in the Swedish graphics industry (81), and there were very few cases in the Danish study (82).

\section{Environmental and occupational agents}

Solvents and related compounds. Exposures to organic solvents are found across a wide spectrum of industries and processes, such as chemical manufacturing, the rubber industry, rayon viscose production, varnishing, insulation, printing, painting and paint manufacturing, the metal industry, technical services, other services and 
cleaning industries, including dry cleaning. In a US casereferent study (83) of ovarian cancer, years of occupational exposure to unspecified solvents was not associated with risk of ovarian cancer. A Chinese case-referent study (17) found a nonsignificant $40 \%$ excess risk for exposure to benzene. Dry cleaning workers have not exhibited consistent excesses of ovarian cancer. (See the preceding section.) A large Danish linkage study (84) did not find an elevated risk for women exposed to formaldehyde. A Finnish cohort study of workers occupationally exposed to halogenated solvents (85) found no excess; however the number of exposed cases was small.

Chlorinated naphthalenes were key agents used in a US cable manufacturing plant during World War II. A mortality follow-up of employees at this plant (86) failed to find any evidence for an excess risk of ovarian cancer.

Pesticides. An association between risk of ovarian neoplasms and triazine herbicides has been reported in an Italian case-referent study (87). This study may have suffered from the usual problem of confounding from other pesticidal agents used by exposed cases.
Polycyclic aromatic hydrocarbons. Polycyclic aromatic hydrocarbons (PAH) have been associated with several types of human cancer in various industries. The only available study on ovarian cancer was a US case-referent study (83) that failed to find an association between years of occupational PAH exposure and the risk of ovarian cancer.

Asbestos and talc. In 1960, Keal (88) reported that women exposed to asbestos appeared to have a higher frequency of ovarian neoplasms than those without such exposure. Newhouse et al (89) found excess deaths from ovarian cancer among women employed at an asbestos factory. This study was based on 9 cases.

Women can be exposed to talc through occupational contact, in mining, talc milling, or the talc product manufacturing industry, but, more commonly, in daily activities through the use of cosmetic talc, baby powder, facial powder, sanitary napkins, and contraceptive devices, the application of talc powder in the perineal area, and talc powder in towels.

Table 2. Epidemiologic data on chemical agents. $(95 \% \mathrm{Cl}=95 \%$ confidence interval, $\mathrm{C}-\mathrm{R}=$ case-referent study, $\mathrm{COH}=0 \mathrm{cccupational}$ cohort study, $R-L=$ record-linkage study, $S I R=$ standardized incidence ratio, $S M R=$ standardized mortality ratio)

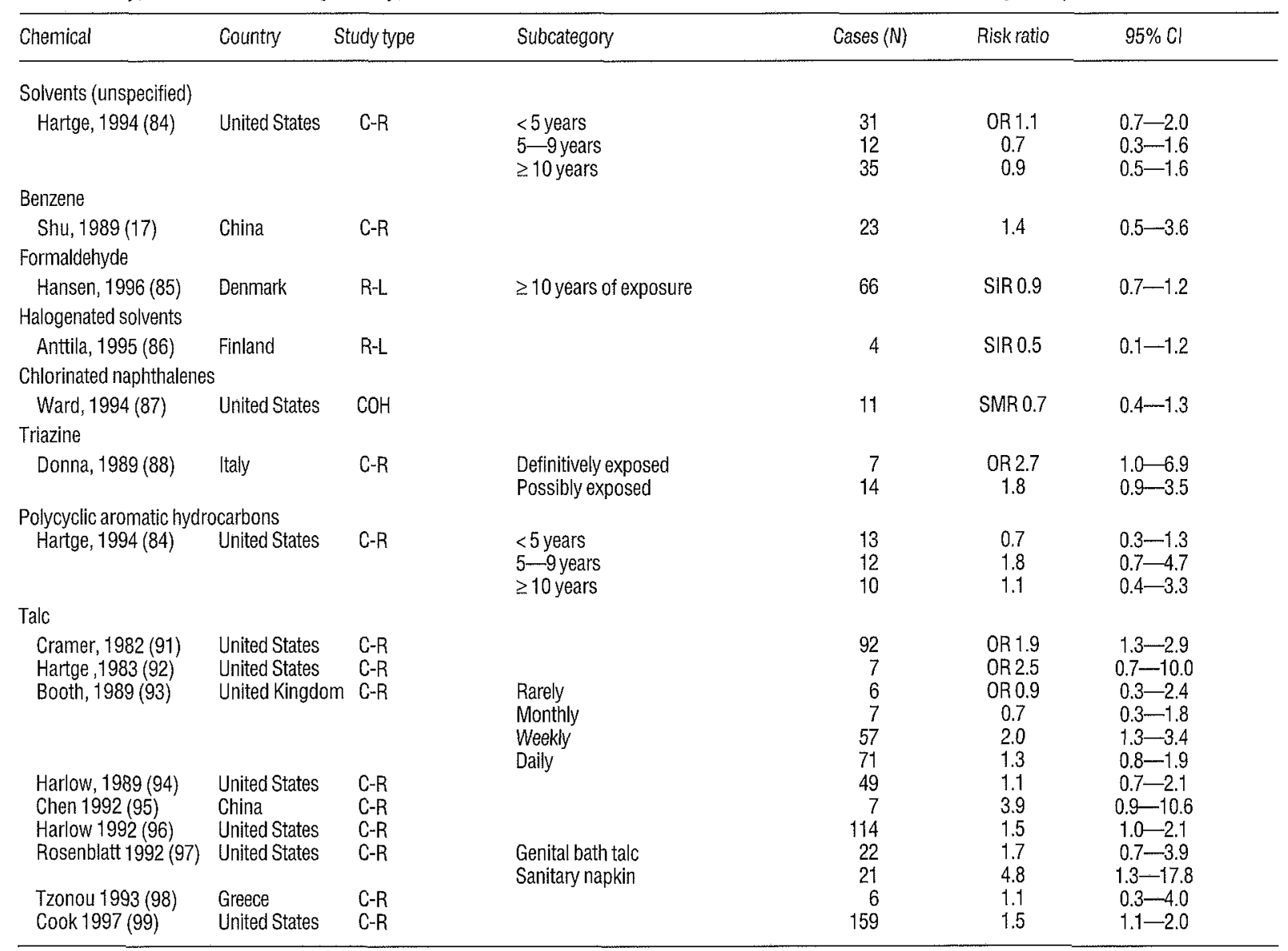


Nine interview-based case-referent studies (90-98) were available for evidence on genital talc application. The 4 largest studies came from the United States $(98,95$, 90 ) and the United Kingdom (90). Each found a 50$90 \%$ excess. The results of the smaller studies were more heterogeneous, the point estimates of the odds ratios exceeding unity in each.

\section{Discussion and concluding remarks}

Considerable international variation in the incidence rates for ovarian cancer, together with results from migrant studies, suggest that either life-style or environmental factors or both may affect risk. The published data are not extensive and suffer from various limitations. Much of the evidence on occupational and environmental risk factors is derived from record-linkage and proportionate mortality studies. Some of the studies had job titles reported crosssectionally. Data on potential confounders such as reproductive history, use of oral contraceptives, hormone replacement therapy, and drugs that induce ovulation were missing in most of the occupational cohort, record-linkage, and proportionate studies. A further limitation of the published studies was the possibility of reporting and publication bias. Given the relative rarity of ovarian cancer, it is possible that increased risks found by chance only have been preferentially reported and published in both cohort and case-referent studies. This problem is particularly relevant to occupations, industries, and agents for which results from only a few studies are available.

In conclusion, the evidence for risks of ovarian cancer in association with job titles, industries, and occupational and environmental agents is not convincing because of the lack of high-quality data. The aggregated evidence for nurses, teachers, professionals, dry cleaners, farmers and farm workers, employees in the pharmaceutical industry and pharmacists, waitresses, and cooks is negative or inconsistent. Hairdressers, beauticians, and women employed in the printing industry may have an increased risk, but the data are insufficient. For the rest of the occupations and industries studied, not enough studies exist on which to base conclusions. There are very few studies on chemical agents in the occupational or general environment, and the evidence is grossly insufficient. The only exception is genital talc application, with 9 interviewbased case-referent studies that provided rather consistent suggestions for a modest-to-moderate excess.

Elucidation of occupational and environmental risk factors of ovarian cancer calls for well-focused, high-quality epidemiologic studies with sufficient study size and valid individual data on histories of exposures to occupational, environmental and life-style factors.

\section{References}

1. Young RC, et al. In: DeVita JTV, et al, editors. Cancer principles \& practice of oncology. Philadelphia (PA): JB Lippincott Co, 1993:1226-30.

2. Parkin DM, et al. Int J Cancer 1993;54:594-606.

3. Tortolero-Luna G, et al. Obstet Gynecol Clin North Am 1994;21:1-23.

4. Yancik R, et al. Cancer 1993;71:514-6.

5. Parkin DM, et al. Cancer incidence in five continents, vol VI. Lyon: International Agency for Research on Cancer (IARC), 1992.

6. Adami HO, et al. Am J Epidemiol 1990;1323:446-52.

7. Coleman MP, et al. Trends in cancer incidence and mortality. Lyon: International Agency for Research on Cancer (IARC), 1993.

8. Parkin DM \& Iscovich J. Int J Cancer 1997;70:654-60.

9. Herrinton LJ, et al. JNCI 1994;86:1336-9.

10. Kogevinas $M$, et al. Social inequalities and cancer. Lyon: International Agency for Research on Cancer (IARC), 1997.

11. Baker TR \& Piver MS. Semin Surgical Oncol 1994;10:242-8.

12. Shoham Z. Fertil Steril $1994 ; 62: 433-48$.

13. Lingeman CH. Am J Ind Med 1983;4:365-79.

14. Lingeman CH. JNCI 1974:53:1063-78.

15. Heintz AP, et al. Obstet Gynecol 1985;66:127--35.

16. Daly MB. Hematol Oncol Clin North Am 1992;6:729-38.

17. Shu XO, et al. Cancer Res 1989;4913:3670-4.

18. Threlfall WJ, et al. J Occup Med 1985;276:448-50.

19. La Vecchia C, et al. JNCI 1984;733:663-6.

20. Parazzini F, et al. Int J Epidemiol 1991;20:871-7.

21. Negri E, et al. Int J Cancer 1991;491:50-6.

22. Chen Y. Chin J of Obstetr Gynec 1991;263:158-61 (In Chinese).

23. McGowan L. Oncology 1989;3(1):51-4.

24. Hartge P, et al. Obstet Gynecol 1994;845:760 - 4.

25. Joly DJ, et al. Am J Epidemiol 1974;99:190-209.

26. Kvale G, et al. Cancer Det Prev 1991;15:369 - 77 .

27. Albrektsen G, et al. Cancer Causes Control 1996;74:4217.

28. Franceschi S, et al. Int J Cancer 1991;491:57-60.

29. Woutersz TB. Int J Fertil 1991;3:26-31.

30. Stanford JL. Contraception 1991;43:543-56.

31. van Leeuwen FE \& Rookus MA. Eur J Cancer Clin Oncol 1989;25:1961-72.

32. Gross TP \& Schlesselman JJ. Obstet Gynecol 1994;83:41924.

33. Whittemore AS, et al. Am J Epidemiol 1992;136:1184203.

34. Whittemore AS. Cancer 1993:71:558-65.

35. Tzonou A, et al. Eur J Cancer Clin Oncol 1984;20:104552.

36. Parazzini F, et al. Gynecol Oncol 1991;43:9-23.

37. Smith EM, et al. JNCI 1984;73:371-6.

38. Kato I, et al. Jpn J Clin Oncol 1989;19:202-7.

39. Whittemore AS, et al. Am J Epidemiol 1988;128:122840.

40. Shai D. Public Health Rep 1986;101:547-52.

41. Polychronopoulou A, et al. Int J Cancer 1993;55:402-7.

42. Leviton A. Cancer Lett 1990;51:91-101.

43. Hildreth NG, et al. Am J Epidemiol 1981;114:398 - 405.

44. Schildkraut JM \& Thompson WD. Am J Epidemiol 1988:123:456-66. 
45. Narod SA, et al. Lancet 1991;338:82.

46. Eccles DM, et al. Oncogene 1990;5:1599-601.

47. Ehlen T \& Dubeau L. Oncogene 1990;5:219-23.

48. Lee JH, et al. Cancer Res 1990;50:2724-8.

49. Cleton-Jansen AM, et al. Br J Cancer 1995;72:1241-4.

50. Gunnarsdóttir H \& Rafnsson V. J Occup Environ Med 1995;37:307-12.

51. Pukkala E. Cancer risk by social class and occupation: contributions to epidemiology and biostatistics. Basel: Karger, 1995:63-76.

52. Costa G, et al. Occupational mortality in Italy in the 1980 s. Rome: Istituto Superiore per la Prevenzione la Sicurezza del Lavoro, 1995. In Italian.

53. King AS, et al. Am J Ind Med 1994;26:125-32.

54. Drever F, editor. Occupational decennial supplement. London: Office of Publications of Censuses and Surveys, Health and Safety Executive, Governmental Statistical Service, 1995.

55. Katz RM. J Occup Med 1983;25:760-2.

56. Zheng W, et al. Cancer 1993;71:3620-4.

57. Carpenter L \& Roman E. Med Lav 1995;86:252-5.

58. Aronson KJ \& Howe GR. J Occup Med 1994;36:1174-9.

59. Kono S, et al. JNCI 1983;70:443-6.

60. Teta MJ, et al. JNCI 1984;72:1051-7.

61. Spinelli JJ, et al. Am J Ind Med 1984;6:97-102.

62. Boffetta P, et al. J Occup Med 1994;36:61-5.

63. Ruder AM, et al. J Occup Med 1994;36:867-74.

64. Lynge E \& Thygesen L. Scand J Work Environ Health $1990 ; 16: 108-12$.

65. Duh RW \& Asal NR. Am J Public Health 1984;74:127880 .

66. Walker JT, et al. Am J Ind Med 1997;32:614-9.

67. Nakamura K. Jpn J Ind Health 1985;27:24-37.

68. Inskip H, et al. Environ Med 1996;53:730-5.

69. Kristensen P, et al. Scand J Work Environ Health 1996;22:14-26.

70. Ronco G, et al. Br J Ind Med 1992;49:220-5.

71. Wiklund K \& Dich J. Cancer Causes Control 1994;5:449-
57.

72. Folsom AR, et al. J Occup Environ Med 1996;38:1171-6.

73. Waterhouse D, et al. Cancer 1996;77:763-70.

74. Dosemeci M \& Blair A. J Occup Med 1994;36:1204-9.

75. Hansen J, et al. Int J Epidemiol 1994;23:891-7.

76. Hansen $\mathbf{J} \&$ Olsen JH. Scand J Work Environ Health 1994;20:22-6.

77. Edling $\mathrm{C}$, et al. Scand J Work Environ Health 1995;21:116-23.

78. Walrath J, et al. Am J Public Health 1985;75:883-5.

79. Gunnarsdóttir H \& Rafnsson V. J Epidemiol Community Health 1992;46:601-4.

80. Burnet CA \& Dosemeci M. J Occup Med 1994;36:1199_203.

81. Malker HSR \& Gemne G. Arch Environ Health 1987;42:73-82.

82. Lynge E, et al. Occup Environ Med 1995;52:738 - 44.

83. Hartge P \& Stewart P. J Occup Med 1994;36:924-7.

84. Hansen J \& Olsen JH. Ugeskr Laeger 1996;158:4191-4. In Danish.

85. Anttila A, et al. J Occup Environ Med 1995;37:797-806.

86. Ward EM, et al. J Occup Med 1994;36:860-6.

87. Donna A, et al. Scand J Work Environ Health 1989;15:4753.

88. Keal EE. Lancet 1960;2:1211-6.

89. Newhouse ML, et al. Br J Ind Med 1985;42:4-11.

90. Cramer DW, et al. Cancer 1982;50:372-6.

91. Hartge P, et al. JAMA 1983;250:1844.

92. Booth $\mathrm{M}$, et al. Br J Cancer 1989;60:4592-8.

93. Harlow BL \& Weiss NS. Am J Epidemiol 1989;130:390-

94. Chen Y, et al. Int J Epidemiol 1992;21:23-9.

95. Harlow BL, et al. Obstet Gynecol 1992;80:19-26.

96. Rosenblatt KA, et al. Gynecol Oncol 1992;45:20-5.

97. Tzonou A, et al. Int J Cancer 1993;55:408-10.

98. Cook LS, et al. Am J Epidemiol 1997;145:459-65.

Received for publication: 24 February 1998 